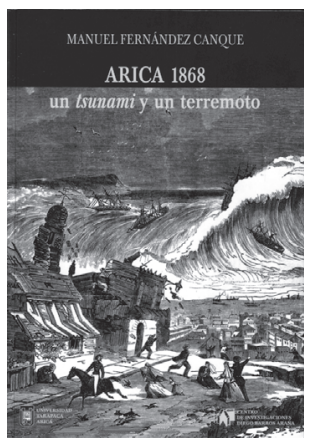

\title{
Manuel Fernández Canque. Arica 1868, un tsunami y un terremoto
}

\author{
Santiago de Chile: Centro de Investigaciones Diego \\ Barros Arana de la Dirección de Bibliotecas, Archivos y \\ Museos (DIBAM), 2007, 332 p.
}

\author{
Carmen Miranda Cuevas ${ }^{1}$
}

Los desastres naturales son capaces de generar daños importantes, desequilibrios sociales y económicos en los lugares afectados. En este contexto, nuestro país, Chile, se caracteriza por ser un país de desastres. Debido a su ubicación frente a una zona de subducción ${ }^{2}$, las amenazas naturales, como los terremotos y tsunamis, constituyen fenómenos recurrentes en la historia del país. Por esta razón, es fundamental contar con antecedentes detallados de la historia sísmica de una región, sobre la cual apoyar los estudios e investigaciones presentes y futuras, relacionadas con este tipo de fenómenos naturales.

En diciembre de 2007 fue lanzado el libro "Arica 1868, un tsunami y un terremoto" del autor Manuel Fernández Canque, destacado profesor de Historia y Geografía, y Doctor en Historia Económica por la Universidad de Glasgow, Escocia. La obra fue publicada y coeditada por el Centro de Investigaciones Diego Barros Arana de la Dirección de Bibliotecas, Archivos y Museos (DIBAM) y la Universidad de Tarapacá de Arica.

La obra de Manuel Fernández Canque se presenta ante el lector no tan solo como una recopilación histórica de este gran evento, sino que además ofrece un cuadro completo de las características del tsunami de 1868, de la realidad en la cual se situaba la ciudad de Arica, y en general, toda la costa de Chile y Perú. Utiliza numerosas fuentes iconográficas y documentales de bibliotecas nacionales y extranjeras, muchas de ellas inéditas hasta el momento.

\footnotetext{
1 Estudiante de Geografía que cursa su último año de carrera. E-mail: cgmirand@uc.cl
}

El texto se estructura en siete capítulos. El capítulo primero corresponde a una introducción a la historia sísmica de Chile y Perú, destacando a famosos cronistas de cada época. El autor elabora una recopilación bibliográfica exhaustiva para mostrar el contexto histórico en el cual se situaba Arica hasta el momento del desastre. Es así como describe la precaria situación de la "villa de Arica", embargada por la pobreza, marginada del auge guanero y viviendo en función del tráfico comercial proveniente de Bolivia y el mercado externo. El autor utiliza un lenguaje sencillo, sin entrar en definiciones complejas ni técnicas, para hacer un relato rico en detalles que nos muestran la vida cotidiana del puerto y la sociedad tradicional del siglo XIX.

Un aspecto que el autor desarrolla con especial atención en el libro es la importante llegada de extranjeros, especialmente británicos y norteamericanos, atraídos por las ganancias del guano y la minería. En relación a esto último, el autor destaca el contraste de realidades de un Perú rico, que invierte en ferrocarriles e infraestructura portuaria, y por otro lado, un país con una enorme masa indígena sometida a injusticias y marginada de los adelantos del siglo.

El segundo capítulo se dedica a narrar el fatídico día del 13 de agosto de 1868, en el cual a las 5 p.m. se sintieron los primeros movimientos del terremoto. Treinta minutos después del terremoto sobrevino el tsunami, el cual terminó por dejar a la ciudad devastada. Miles de historias sucedieron simultá-

\footnotetext{
2 Zona de convergencia en la cual se produce deslizamiento de una placa litosférica bajo la otra.
} 
neamente, cada una con su propio personaje. Como dice el autor: "Cada familia, cada habitante y cada marinero vivió su propio tsunami. ¿Cómo saber cuál fue cada historia? ¿Cómo contar las que se saben, en un modo simultáneo, qué es como ocurren las cosas en la vida real de esos momentos?". Este capítulo nos muestra la reacción que tuvo la población ante el terremoto y posterior tsunami de 1868, cómo la cultura sísmica de los ariqueños de aquella época les sirvió para salvar vidas y cómo la falta de esta la convierte en vulnerable.

Una parte importante del libro es la recopilación de información en otras lugares de Perú. El autor recoge información de Iquique, la cual tenía un crecimiento mayor que Arica por ser puerto de exportación salitrera. En esta ciudad el daño fue máximo, aunque afirma el autor, con una intensidad menor. También se describen los daños causados en Tacna, el centro urbano más importante cercano al puerto. También recopila fuentes primarias (cartas y telegramas) de Lima y Callao, Arequipa, Islay, Moquegua, etc.

El capítulo siguiente es dedicado de manera especial a las naves que estaban en el puerto al momento del tsunami. El autor, en este aspecto, hace un valioso esfuerzo por investigar detalladamente acerca de las naves más importantes, las cuales eran principalmente británicas, norteamericanas, peruanas y francesas. Entre ellas estaba el buque de guerra norteamericano Wateree, al mando del capitán James Gillis y su segundo comandante Moses Sherwood Stuyvesant, quien debió dirigir la nave durante el tsunami. Otras naves importantes fueron el Fredonia, también de propiedad norteamericana, la corbeta peruana de guerra América, el barco británico Santiago y la barca inglesa Chañarcillo.

Los dos capítulos posteriores se refieren a casos y testimonios de personajes importantes por la valiosa descripción que hacen del terremoto y tsunami, recogida en numerosas cartas y diarios de la época. Son en su mayoría escritas por diplomáticos ingleses, capitanes y oficiales de barco y viajeros extranjeros, como es el caso del diario de Frederick James Stevenson, a quien se le dedica una buena parte del capítulo. Una vez más se destaca el uso de imágenes y mapas de la época, y el minucioso trabajo de recopilación de testimonios, muchos de ellos traducidos directamente por el autor.

En los últimos párrafos, el autor se refiere en el epílogo a las consecuencias del terremoto y tsunami para la economía y sociedad del Perú. El desastre de 1868 vino a agravar una crisis económica emergente, a lo cual se suma una mala gestión del gobierno para la reconstrucción de los pueblos afectados. Otro de los aspectos destacados de estas notas finales es la dimensión universal con la cual se analiza el terremoto y tsunami, haciendo referencia al mundo científico de 1868, época en la cual se desarrollaba un creciente interés por comprender los fenómenos naturales de este tipo.

Para terminar, el autor sugiere un replanteamiento sobre el tema de los desastres naturales, apuntando a que sus causas están más bien ligadas a la pobreza, a la imprevisión humana y la ausencia de desarrollo, más que a los fenómenos naturales en sí. En este sentido, resulta interesante la comparación que se hace entre las poblaciones originarias, cuyas viviendas eran construidas en función de la amenaza sísmica, y el colonizador urbano, que llegó a ocupar lugares inseguros en busca de la explotación de los recursos.

\section{Consideraciones finales}

A modo general, la obra comentada es un excelente aporte a la recuperación de la cultura e historia regional de Arica. De fácil lectura, está dedicada al público en general y aquel que se interese en los desastres naturales históricos. Si bien esta obra pertenece al ámbito de la historia, aborda temas de interés para la ciencia geográfica, en la forma que se articulan las intervenciones humanas y las limitaciones del sistema físiconatural, y las implicancias que tiene la consideración de los riesgos naturales en la planificación del territorio. El libro nos muestra que el ordenamiento del espacio resultante de la aplicación de criterios exclusivos de rentabilidad económica puede dar lugar a disparidades territoriales insostenibles en el tiempo. 